\title{
EVALUATING THE EFFECTIVENESS OF A TWO YEAR REHABILITATION OF A PATIENT WITH GUILLAIN-BARRE SYNDROME: A CASE REPORT
}

\author{
Agnė Timleryte் ${ }^{1}$, Lolita Grygalyte் ${ }^{1}$, Aleksandra Kubiliūté $\dot{e}^{1}$, Raimondas Savickas ${ }^{2}$ \\ ${ }^{1}$ Lithuanian University of Health Sciences, Academy of Medicine, Faculty of Medicine \\ ${ }^{2}$ Lithuanian University of Health Sciences hospital Kaunas Clinics, Department of Rehabilitation
}

Keywords: Guillain-Barre syndrome, rehabilitation, subacute demyelinating polyneuropathy.

\begin{abstract}
Summary
Aim: To present a clinical case of multiple multidisciplinary rehabilitation courses after a total of three episodes of Guillain-Barre syndrome (GBS).

Case report: A 72-year-old female was hospitalized to Lithuanian University of Health Sciences (LUHS) Hospital Kaunas Clinics Neurology department, complaining of lower back pain spreading to the lateral surfaces of both legs and a cold, tingling sensation in her feet that has been continuing for two months. Subacute demyelinating polyneuropathy was diagnosed. The patient suffered a total of three episodes of GBS and underwent a course of multidisciplinary rehabilitation after each of them. Despite the worsening condition during every episode of GBS, improvements were observed in the Barthel index, Functional Independence Measure, Lovett scores and dynamometry after each course of rehabilitation. Physiotherapy, occupational therapy, massage, transcutaneus electrical nerve stimulation, physical therapy, speech therapy, psychologist consultation and social worker consultation were applied. After the last course of rehabilitation, our patient was autonomous within the range of a ward, able to eat served food, put clothes on the upper body with minimal help, on the lower body - with moderate help. Moderate help was needed for all other activities. Conclusions: After undergoing multidisciplinary in and outpatient rehabilitation, the condition of our patient improved. This case highlights the importance of both early inpatient and continuous long-term rehabilitation for the achievement of the maximum functional recovery.
\end{abstract}

Introduction

Guillain-Barre syndrome (GBS) is an acute or subacute immune-mediated polyradiculoneuropathy, typically characterized by symmetrical weakness of the limbs or cranial nerve-innervated muscles and hyporeflexia [1,2]. The exact mechanisms of GBS are not entirely clear, however, it is thought to be an immune-mediated process. The immune response is usually triggered by bacterial/viral infections or vaccines - microorganisms express lipooligosaccharides similar to gangliosides, which trigger the synthesis of antiganglioside antibodies. Autoimmune antibodies and inflammatory cells cross-react with neural antigens, which can lead to demyelination, axonal damage or both $[1,3]$. The main phenotypes of GBS are acute inflammatory demyelinating polyneuropathy (AIDP), which is a result of the myelin sheath and Schwann cell components injury and acute motor axonal neuropathy (AMAN), which occures when the membranes of the nerve axon are damaged [4]. The disease usually presents with progressing bilateral and relatively symmetric limb weakness [5]. GBS often affects cranial nerves resulting in facial, oculomotor, or bulbar weakness. Furthermore, patients may present with sensory signs, ataxia and autonomic dysfunction. Muscle or radicular pain, oftentimes in the spinal region, is also a frequent complaint and could also be the first symptom of GBS, complicating the initial diagnosis [6]. Diagnosis is established upon clinical symptoms, cerebrospinal fluid testing and nerve conduction studies. After the diagnosis is made, patients should be hospitalized for multidisciplinary supportive care and diseasemodifying treatment [3]. When started within a period of the first 2 weeks after onset of weakness, intravenous immunoglobulin therapy (IVIg) is recommended and proven to be effective for patients who are incapable of walking unaided. Plasma exchange is the most effective when started within the first 2 weeks after onset of weakness as well, however the benefits could be seen when started up to 4 weeks after onset [7]. Regardless, $20 \%$ of patients continue to have severe symptoms [8]. It's important to acknowledge the significance 
of including rehabilitation in the multidisciplinary care for GBS, considering that acute inflammatory demyelinating polyneuropathy can cause significant long-term disability. There is evidence that ambulatory multidisciplinary high intensity rehabilitation might help to produce long-term advantages in terms of activity and participation [9] .

The aim of this article was to present a case report of a patient who experienced a total of three episodes of GBS and underwent a course of multidisciplinary rehabilitation after each of them.

\section{Clinical case}

A 72-year-old female was hospitalized to Lithuanian University of Health Sciences (LUHS) Hospital Kaunas Clinics Neurology department 24th December 2018, complaining of lower back pain spreading to the lateral surfaces of both legs and a cold, tingling sensation in her feet that has been continuing for two months. A sacrolumbar computer tomography (CT) scan was performed and revealed moderately narrowed intervertebral cavities in L3/L4, L4/L5 segments, significant stenosis in L5/S1 segment, a central intervertebral disc hernia which caused $1.1 \mathrm{~cm}$ cerebral canal stenosis in L5/S1 segment.

Two months later, due to the persistent condition, the patient set up an appointment at general practitioners' office and has been referred to the Emergency department of LUHS hospital Kaunas Clinics where she was consulted by a neurologist and hospitalized to the Neurology department for further examination and treatment. During that time, the patient was evaluated for differentiation of vertebral pathology and demyelinating polyneuropathy. Objective findings: proximal leg muscle strength was evaluated for 3 points, distal -4 points. Deep tendon reflexes in arms were as follows: biceps reflex was equally weakened in both arms $(\mathrm{l}=\mathrm{r})$, triceps, brachioradial, carporadial reflexes were absent in both arms. Deep tendon reflexes in both legs were also absent. Distal hypoesthesia in both arms and legs was found. Diagnostic tests were performed and on electroneuromyography similar findings to demyelinating sensory and motor neuron axonal polyneuropathy prevailing significant motor neuron demyelination and desynchronization were found, $1.11 \mathrm{~g} / 1$ of protein and $5 \times 10 * 6 / 1$ cytosis was identified in the cerebrospinal fluid. The patient was diagnosed with subacute demyelinating polyneuropathy (Guillain-Barre syndrome). Treatment with a total of $130 \mathrm{~g}$ of immunoglobulin (Octagama) was administered. After the first stage rehabilitation patient was referred for the second stage to the Rehabilitation Hospital of Kulautuva.

During the second stage rehabilitation the patient was transferred back to the Neurology department due to a wor- sening neurological condition, weakened muscle strength and dyskinesia. A pulmonary embolism was diagnosed which was a probable cause of the symptoms. After anticoagulative treatment with nadroparin (Fraxiparine), warfarin administration was started. Patient was referred to further rehabilitation to the Department of Neurorehabilitation. The patient was evaluated as conscious and cooperative, able to understand and carry out instructions, answered the questions meaningfully and speech was intact. Eye movements were intact in all directions, with a mild horizontal nystagmus to the left. Face was symmetrical, eyebrows raised symmetrically and tongue was in midline. Applied rehabilitation methods: physiotherapy, occupational therapy, massage, TENS, psychologist consultation, social worker consultation. During two months of rehabilitation the patients Functional Independence Measure (FIM) increased from 45 to 53 points, Barthel index increased from 15 to 20 points. Lovett scores remained impaired in all extremities (4 proximally and 3 distally in left arm, 3 proximally and distally in right arm, 2 in both legs). Dynamometry increased from $0,5 \mathrm{~kg}$ to $1 \mathrm{~kg}$ in both hands. On discharge the patient used pincer grasp to get ahold of things although often dropping them. Minimal to moderate help was needed to eat served solid food with a thick handle spoon. Maximum help needed in all other activities. After discharge, the patient was referred to ambulatory rehabilitation.

Due to the worsened condition five months later, the patient was readmitted to the Neurology department complaining of weakness in both arms and in both legs. Paresthesias' were reported worse in the right limbs. Pain manifested as cramp-like pain in the arm. Patient received treatment with plasmapheresis (treatment discontinued due to a significant decrease in serum protein), intravenous immunoglobulin therapy. First stage rehabilitation was conducted in the Neurology department and later the patient was transferred to the Neurorehabilitation department for further rehabilitation. Physiotherapy, occupational therapy, massage, physical therapy, psychologist consultation and social worker consultations were performed. After this course the Barthel index improved from 10 to 15 points, FIM improved from 43 to 50 points. Lovett scores were 4 points proximally and distally in left arm, 3 points proximally and distally in right arm, 1 proximally and 0 distally in left leg and 2 proximally and 0 distally in right leg. Dynamometry improved from $0 \mathrm{~kg}$ to $1,5 \mathrm{~kg}$ in right and 2,6 kg in left hand. On discharge patient was able to eat served food, could transfer to and from the wheelchair with maximum assistance, had partial control of bladder function, but constant supervision and assistance in self-service were required.

One year later the disease exacerbated, patient com- 
plained of weakness in both arms and legs, cramping of leg muscles, painful finger flexion contracture and stress incontinence. The patient was readmitted for treatment and rehabilitation. Physiotherapy, occupational therapy, massage, physical therapy, speech therapy, psychologist consultation and social worker consultation were applied. Subsequently, the Barthel index tested in fitted surroundings has increased from 30 to 40 points, FIM from 64 to 71 points, Lovett scores to 4 in all extremities. Dynamometry results are $9,5 \mathrm{~kg}$ in the right hand and $9 \mathrm{~kg}$ in the left hand. The patient's functional independence has improved - she is autonomous within the range of a ward, able to eat served food, put clothes on the upper body with minimal help, on the lower body - with moderate help. Moderate help is needed for all other activities. Changes in patients' Barthel index and FIM scores during each GBS episode are shown in Figure 1.

\section{Literature review}

GBS is more common among males than females, its incidence ranges from 0.8 to 1.9 cases per 100000 people per year and increases exponentially with age [1]. This disease is associated with a variety of infections, the main one being Campylobacter jejuni. Other infections include cytomegalovirus (CMV), Epstein-Barr virus, influenza A virus, M. pneumoniae, H. Influenzae and hepatitis E. Some cases of GBS have been reported after rabies and Influenza type A vaccine. Mortality rates range from 3 to $7 \%$ [6].

Multidisciplinary care is important in order to avoid and treat potential complications and other symptoms. This includes assessing the need for admission to the intensive care unit when the patient requires mechanical ventilation or severe progressing weakness and autonomic dysfunction are present, pain management, prophylaxis for infections and deep vein thrombosis and psychosocial support and rehabi-

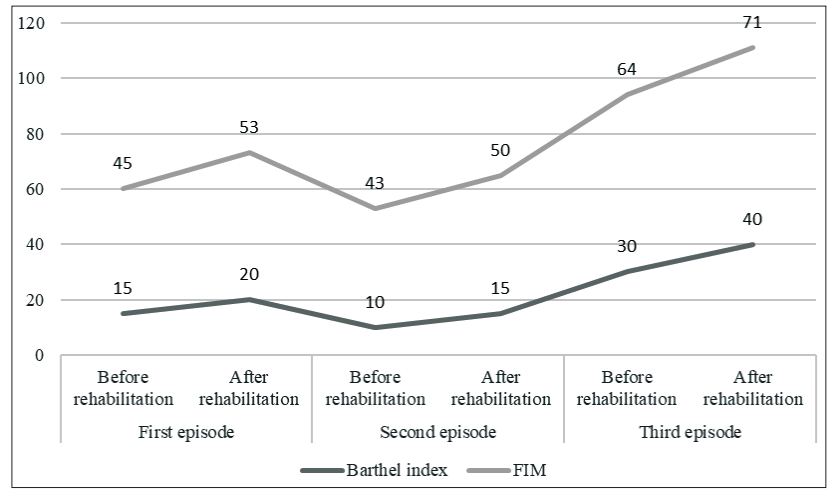

Figure 1. Barthel index and functional independence measure (FIM) scores during each episode of GBS, measured before and after rehabilitation litation [10]. However, even with a proper treatment, this syndrome remains a serious and life threatening condition. Those who survive GBS have frequent remaining complaints and functional deficits. This might have a considerable effect on their everyday activities and quality of life. The most common complaints include residual pain and fatigue. Up to $20 \%$ of patients are still unable to walk unaided for 6 months after the onset of GBS [6].

GBS can be a remarkable cause of long-term disability and over a third of all GBS patients are in need of rehabilitation, especially those who require ventilation or are more severely disabled. There is evidence that ambulatory multidisciplinary high intensity rehabilitation might help produce long-term advantages in terms of activity and participation [9]. A randomized controlled trial, conducted in 2011, assessed the effectiveness of 12 months of high versus low intensity multidisciplinary ambulatory rehabilitation in the chronic phase of GBS. The results showed that high intensity interventions, in comparison with lower intensity rehabilitation programme, significantly reduces disability in late stages of GBS. This raises the possibility that post-GBS rehabilitation should consist of two phases: one in the early stages of recovery to diminish the weight of disability; and one in the later stages to enhance the functional status and involvement in daily activities [11]. This is also supported by a retrospective study that analyzed the outcomes of up to one year of post-GBS rehabilitation. The results of this study found that after the total rehabilitative treatment only 4 $\%$ of patients were still unable to walk and only $8 \%$ needed support while walking. This proves that although the recommended duration of rehabilitation after a GBS episode is 2-3 months, the best results are achieved in a year or more [12].

Enhancing or reimposing physical abilities is of key importance in post-GBS rehabilitation. The benefits of physical therapy and exercise are analyzed most widely - there is limited evidence that these interventions significantly improve muscle strength, fatigue, fitness, functional independence and quality of life [9]. A literature review conducted by Arsenault et al. reported that assorted exercise programs such as cycling training and various physiotherapy interventions, lasting around 12 weeks and including 30-60 minutes of exercise three times per week, improve GBS physical outcomes by increasing muscle strength, reducing fatigue and increasing overall physical capacity [13]. Nevertheless, studies suggest that muscle groups should not be overworked, thus exercise programs should be non-fatiguing and more aggressive techniques can be applied only as muscles regain strength. Other possible rehabilitation interventions for patients with GBS include physical therapy and exercise, transcutaneous electrical nerve stimulation (TENS), occupational and re- 
creational therapy, speech and nutritional therapy, cognitive and psychological interventions, etc. [9]

However, the data available on rehabilitation after GBS is limited, thus future studies, as well as development of clear guidelines, are required in order to determine the necessary elements of rehabilitation intervention [9,11]. There is a need of high quality clinical trials in order to assess the effectiveness of specific rehabilitation methods, their duration, intensity and frequency of sessions $[12,14]$.

\section{Conclusions}

After undergoing multidisciplinary in and outpatient rehabilitation, the condition of our patient improved. This case highlights the importance of both early inpatient and continuous long-term rehabilitation for the achievement of the maximum functional recovery.

\section{References}

1. Sejvar JJ, Baughman AL, Wise M, Morgan OW. Population incidence of Guillain-Barré syndrome: a systematic review and meta-analysis. Neuroepidemiology 2011;36:123-33. https://doi.org/10.1159/000324710

2. Kaida K. Guillain-Barré syndrome. In: Advances in Experimental Medicine and Biology. Springer; 2019:323-31. https://doi.org/10.1007/978-981-32-9636-7_20

3. Walling AD, Dickson G. Guillain-Barré syndrome. American Family Physician 2013;87.

4. Malek E, Salameh J. Guillain-Barre syndrome. Seminars in Neurology. 2019;39(05). https://doi.org/10.1055/s-0039-1693005

5. Yuki N, Hartung H-P. Guillain-Barré syndrome. New England Journal of Medicine. 2012;366(24):2294-304. https://doi.org/10.1056/NEJMra1114525

6. Willison HJ, Jacobs BC, van Doorn PA. Guillain-Barré syndrome. Lancet 2016;388:717-27. https://doi.org/10.1016/S0140-6736(16)00339-1

7. van den Berg B, Walgaard C, Drenthen J, Fokke C, Jacobs BC, van Doorn PA. Guillain-Barré syndrome: pathogenesis, diagnosis, treatment and prognosis. Nature Reviews Neurology. 2014;10(8). https://doi.org/10.1038/nrneurol.2014.121

8. Xiao J, Simard AR, Shi FD, Hao J. New strategies in the management of Guillain-Barré syndrome. Clinical Reviews in Allergy and Immunology 2014;47: 274-88. https://doi.org/10.1007/s12016-013-8388-5

9. Khan F, Amatya B. Rehabilitation interventions in patients with Acute demyelinating inflammatory polyneuropathy: a systematic review. Eur J Phys Rehabil Med 2012;48:507-22.

10. van Doorn PA. Diagnosis, treatment and prognosis of GuillainBarré syndrome (GBS). La Presse Médicale 2013;42(6). https://doi.org/10.1016/j.lpm.2013.02.328
11. Khan F, Pallant J, Amatya B, Ng L, Gorelik A, Brand C. Outcomes of high- and low-intensity rehabilitation programme for persons in chronic phase after Guillain-Barré syndrome: a randomized controlled trial. Journal of Rehabilitation Medicine 2011;43(7) https://doi.org/10.2340/16501977-0826

12. Prada V, Massa F, Salerno A, Fregosi D, Beronio A, Serrati $\mathrm{C}$, et al. Importance of intensive and prolonged rehabilitative treatment on the Guillain-Barrè syndrome long-term outcome: a retrospective study. Neurological Sciences 2020;41(2). https://doi.org/10.1007/s10072-019-04077-x

13. Simatos Arsenault N, Vincent P-O, Yu BHS, Bastien R, Sweeney A. Influence of exercise on patients with GuillainBarré syndrome: a systematic review. Physiotherapy Canada 2016;68(4).

https://doi.org/10.3138/ptc.2015-58

14. Khan F, Ng L, Amatya B, Brand C, Turner-Stokes L. Multidisciplinary care for Guillain-Barré syndrome. The Cochrane database of systematic reviews 2010;47(10):CD008505.

https://doi.org/10.1002/14651858.CD008505.pub2

\section{PACIENTĖS, SERGANČIOS GIJENO-BARE SINDROMU, DVEJŲ METU REABILITACIJOS EFEKTYVUMO IVERTINIMAS}

A. Timlerytė, L. Grygalytė, A. Kubiliūtė, R. Savickas

Raktažodžiai: Giljeno-Bare sindromas, reabilitacija, poūmė demielinizuojanti polineuropatija.

Santrauka

Tikslas - pristatyti klinikinį atvejị, kurio esmè - kartotiniai multidisciplininès reabilitacijos kursai po trijų Gijeno-Bare sindromo (GBS) epizodų.

Klinikinis atvejis. I Lietuvos sveikatos mokslų universiteto (LSMU) ligoninės Kauno klinikų Neurologijos kliniką buvo hospitalizuota 72 metų moteris, besiskundžianti prieš du mènesius atsiradusiu juosmens skausmu, plintančiu i abiejų kojų lateralinius paviršius, pèdų tirpimu ir šalimu. Diagnozuota poūmè demielinizuojanti polineuropatija. Paciente iš viso patyre tris GBS epizodus, po kiekvieno iš jų praèjo multidisciplininės reabilitacijos kursą. Nepaisant to, jog pacientès būklè pablogèdavo GBS epizodo metu, po kiekvieno reabilitacijos kurso buvo stebimas Bartelio indekso, funkcinio nepriklausomumo testo, Lovett balų bei dinamometrijos rezultatų pagerėjimas. Buvo taikoma fizioterapija, ergoterapija, masažai, transkutaninè elektrinè nervų stimuliacija, kineziterapija, kalbos terapija, psichologo bei socialinio darbuotojo konsultacijos. Po paskutinio reabilitacijos kurso pacientè buvo savarankiška palatoje, gebėjo pavalgyti paduotą maistą, viršutinę kūno dali apsirengti su minimalia, o apatinę - su vidutine pagalba. Kitoms veikloms buvo reikalinga vidutinè pagalba.

Išvados. Pacientès būklẻ pagerèjo, praejjus multidisciplininès stacionarinės bei ambulatorinès reabilitacijos kursus. Sis atvejis pabrěžia ankstyvos stacionarinès bei tęstinès ilgalaikès reabilitacijos svarbą, norint pasiekti maksimalų funkcinị pasveikimą.

Adresas susirašinèti: agne.01.21@gmail.com

Gauta 2021-03-22 